(C) Elsevier Sequoia S.A., Lausanne - Printed in the Netherlands

\title{
THREATS TO THE PRESIDENT REVISITED
}

\section{ROBERT F. BORT}

University of Michigan Alcoholism and Drug Abuse Clinic, 900 Wall Street, Ann Arbor, Mich. 48105 (U.S.A.)

(Received May 25, 1976; in revised form November 29, 1976; accepted March 2, 1977)

\section{SUMMARY}

Ten prisoners charged with "threatening the President of the United States" were evaluated in an effort to seek out psychiatric and sociological factors involved in this offence. Comparisons were made with known presidential assassins. A history of abandonment as a child, single or divorced state, and a diagnosis of paranoid schizophrenia were prominent in both the study group and the group of known assassins. Additionally, the apparent psychological need behind both the threats and the actual assassinations appeared remarkably similar in both groups. The primary differentiating variable related to lethality was "opportunity and happenstance". It is proposed that those threatening the President by letter are at high risk for carrying out their threat if intervention does not take place.

\section{INTRODUCTION}

From time to time throughout the years the American people have had their sensibilities jolted by assassination attempts upon their president. The past decade alone has witnessed such tragedy as the assassination of President John F. Kennedy. In addition, there have been assassinations of other political figures, including Robert Kennedy, Medgar Evers, Reverend Martin Luther King, and George Lincoln Rockwell, the leader of the American Nazi Party. In the more immediate past there have been assassination attempts on President Gerald Ford and Governor George Wallace during his campaign seeking presidential nomination.

The literature is replete with studies of those who have actually attempted presidential assassination [1-3]. The purpose of this paper, however, is to systematically study some of the biological, sociological, psychological and demographic variables in a group of offenders who have threatened the president's life by written communication and were then apprehended. An effort will then be made to compare the "letter writers" with the actual "assassin group" - nine men who killed or attempted to kill United States presidents ranging from Richard Lawrence, who attempted to kill Andrew Jackson, to Lee Harvey Oswald. 


\section{BACKGROUND}

Perhaps the most complete review of assassination attempts on United States presidents was compiled by Hastings [1]. His conclusion was that of the eight attempts made, four of which were successful, seven were the products of the assassins' disturbed minds. The exception was the attempt on Harry S. Truman by two Puerto Rican nationalists. In Hasting's opinion, each of the other seven assassins suffered from paranoid schizophrenia. He speculated that hatred of a powerful father before whom a boy is helpless can become a murderous loathing with the father, later symbolized by authority figures in general.

Rothstein [2] studied 11 offenders charged with threatening the president and formulated a "Presidential Assassination Syndrome". This group purportedly exhibited a more benign syndrome than those who attempted assassination. He also studied Lee Oswald [3] and on the basis of his studies, attempted a formulation of the personalities of these offenders. He stressed preoedipal factors and maternal deprivation resulting in severe rage against women centered around unmet dependency needs. Paternal absence (passive or absent father) was felt to be a cause for displacement of this rage from the mother to the father. Defective self-identity was also believed to be part of the syndrome.

Weisz [4] in his review of the literature on assassinations felt that all of the victims increased their own vulnerability by exposing themselves "unnecessarily". He also noted society's contribution by presenting an inconsistent allilude toward killing as a means of conflict resolution and by lacking an adequate system of registering grievances. He proposed stronger gun control legislation, legislation regulating pre-announced exposure of presidents to large crowds, and establishment of an ombudsman system for processing complaints against government agencies.

Croty [5], divided assassinations into four categories: (i) elite substitution, in which the leader is replaced by an opposing group of the same level, e.g., palace guard take-over; (ii) tyrannicide which is the murder of a despot, e.g., the Czar; (iii) the terrorist type, to enlist the support of the population in a revolutionary movement by instilling fear, e.g., Viet Cong in Vietnam, and (iv) the anomic variety, seen in the U.S. In the latter, the assassin is acting on an individual basis. He generally has very private reasons for the assassination, with his fantasy life relating in some way to the act.

\section{METHOD}

The entire number of specified offenders $(N=10)$ incarcerated at a midwestern institution housing all mentally ill federal prisoners were the study group. Each had been charged with "threats against the president and successors to the president" [6]. The study spanned a three month period during the early 1970's. The institution serves a geographic area comprising the 
TABLE 1

Demographic and diagnostic comparisons

Study group

Assassin group

$(N=10)$

$(N=9)$

Age

0-19 years

$1(10 \%)$

$0(0 \%)$

20-44 years

$7(70 \%)$

$9(100 \%)$

45-64 years

$2(20 \%)$

$0(0 \%)$

$65+$ years

$0(0 \%)$

$0(0 \%)$

Sex

All male

All male

Ethnic group

Caucasian, U.S. born

Caucasian, foreign born

$10(100 \%)$

$0(0 \%)$

$4(44 \%)$

Other races

$0(0 \%)$

$5(56 \%)$

$0(0 \%)$

Marital Status

Single

$5(50 \%)$

$6(67 \%)$

Married

$1(10 \%)$

$2(22 \%)$

Divorced or separated

$4(40 \%)$

$1(11 \%)$

Widowed

$0(0 \%)$

$0(0 \%)$

Diagnosis

Schizophrenia (paranoid, latent chronicundifferentiated)

Personality disorder (inadequate, antisocial, paranoid)

No psychiatric disorder

Drug dependency as secondary diagnosis

$8(80 \%)$

$2(20 \%)$

$0(0 \%)$

$6(60 \%)$
$7(78 \%)$

$0(0 \%)$

$2(22 \%)$

$1(11 \%)$

United States and its possessions. The number of similar offenders (if any) during that period in regular federal prison was unfortunately not available. An "assassin group" of nine men who assassinated or attempted to assassinate a president were the comparison group.

Personal data was collected for each patient in the "threat group" from psychiatric records, presentence social work evaluations, psychological tests, and central criminal files. Information on the "assassin group" was collected through a study of the appropriate psychiatric and sociological literature $[1,3,5]$. Personal interviews for the study group were undertaken when possible (six subjects), and existing psychiatric evaluations were utilized for the other four.

\section{RESULTS}

Baseline demographic data for both groups are shown in Table I. The 20-44 year age span had the highest representation in both groups. All 
offenders in both groups were males. Single or divorced and widowed offenders accounted for $90 \%$ and $78 \%$, respectively, of the "threat" and "assassin" groups. Educationally, six of the "threat group" failed to advance beyond the eighth grade, four reached high school, and one was a college graduate. Comparable education data was not available for the "assassin group". All subjects were of the Caucasian race. The diagnoses were predominantly forms of schizophrenia (primarily paranoid) for both the "threat group" (80\%) and the "assassin group" $(78 \%)$. Drug abuse was a secondary diagnosis in six out of the ten patients in the "threat group".

\section{REPORT OF CASES}

In order to demonstrate the heterogenicity of the "threat" group, three brief case histories are presented.

\section{Case I}

A white male in his late teens, while AWOL, sent several threatening postcards to the President. A relative revealed his identity to authorities. A catalogue order for a rifle was found in his room along with documents concerning the assassination of President Kennedy.

The patient's mother died when he was age eight. He had a marked hatred for his father. As a child he was a firesetter and after adolescence used hard drugs. He had a long history of incorrigible behavior as a youth.

The patient was delusional, paranoid, hostile and very negativistic.

\section{Case II}

The patient, a male in his early thirties was an achondroplastic dwarf. His family rejected him because of his appearance, especially his father, who "never took him fishing". Since the age of 16 , he had been almost continually in trouble with the law, amassing 21 arrests for a wide variety of offenses. While intoxicated during a period of freedom, he called the FBI and told them to come and get him or he would kill the President: "I'm nothing, but Richard Nixon is nothing". When sober, he allowed that he desired incarceration because he "just couldn't make it on the outside".

\section{Case III}

A male patient in his early twenties had a documented history of explosive, dangerous behavior dating back to age four (stabbing other children in the eyes with pencils, etc.). He had been institutionalized most of his life for various offenses and incorrigible behavior. He would occasionally exhibit bizarre behavior and frequently mutilated himself. On one occasion, he "lapped blood from the floor like a dog" fulluwing a fight between two other inmates. He was thought of as a manipulator by prison personnel and inmates.

His threats to the President were written while in state prison facing an unrelated murder charge. 


\section{DISCUSSION}

The most impressive factor in the history of the "threat group" is the almost total lack of parental warmth and guidance. Five lost mothers by death or abandonment before eight years of age, while gross rejection or severe physical abuse occurred in four other cases. Hatred of the father and/or absence of the father was prominent in seven of the ten study patients. The small number of subjects in this study precludes drawing any statistically significant conclusions on these observations, however. Similar$\mathrm{ly}$, in the "assassin group" the theme of parental neglect is prominent. G. Zangara, who unsuccessfully attempted to kill President F. D. Roosevelt, was removed from school at the age of 6 and put to work at this fathers' insistence. He subsequently developed an intense rage against all authority figures and eventually blamed the "capitalists" for his miserable childhood. J. W. Booth, President A. Lincoln's assassin, was raised by an over indulgent mother and a violent father who suffered from a psychotic disorder.

Concerning dynamic factors in assassinations, there is an apparent contradiction between Hasting's speculation about the "hated father" with Rothstcin's conclusion on the "hated mother". Societal prohibition against hating the mother figure as well as the stark reality of dependence on the mother could result in hatred for the father when either father, mother, or both could be the real object of the hatred.

The classification of assassinations by Croty [5] leads to interesting political speculation. Certainly, the definition of tyrant, despot and so forth is dependent upon which side of the palace wall one is on. Whether a given attempt at assassination is attributed to a mentally ill person or a patriot could well be related to its historical context and even its outcome.

It is difficult to generalize on the lethality of the "study group" concerning their potential to carry out their threats. A task force of the American Psychiatric Association [7] recently concluded that determinations of dangerousness should not be a matter of clinical determination in view of insufficient data in this area and emphasized the very low reliability of such predictions. However, common sense would dictate considering as "serious" a death threat made to any individual, especially when made by an individual suffering from a psychotic disorder with persecutory trends.

\section{COMMENTS}

Attempts at assassination of public figures are becoming a phenomenon of increasing concern in the United States. An effort has been made in this paper to present additional data concerning factors leading to such acts by the study of those charged with making threats against presidents.

A composite of this type of offender seen in the study was a white male in his mid-thirties who had paranoid schizophrenia for several years duration, whose early life has been marked by parental rejection, severe abuse or 
abandonment. Threats to the president seem to represent a projection of anger at an all-powerful authority figure who is fantasied as responsible for the individual's failures and losses. In the "assassin group" similar persecutory trends are noted. R. Lawrence was concerned that President A. Jackson was trying to cheat him out of a fortune; L. Czolgosz planned to murder President W. McKinley for the "good of the working people"; prior to successfully assassinating President J. Kennedy, L. Oswald tried to kill a general he despised.

It would appear from this study and from a review of the literature on assassinations (threatened, attempted or completed) that complete investigations of threats received by major political figures should be undertaken. Mandatory clinical evaluation of the offender is advisable at some point in the judicial proceedings. Strong hostile affect, persecutory delusions involving authority figures, recent financial upheaval or job loss, loss of a loved one, single or divorced state, a recent severe blow to self-esteem, or abuse of alcohol or drugs, appear to increase the likelihood of an assassination attempt. Specific preparations or past violent acting out would be ominous. Government officials receiving communications for public figures need to be fully aware of the necessity of attending to the plcas and complaints of individuals and even minor incidents must not be dismissed lightly. President J. Garfield's assassin attended the Republican convention in 1880 to offer his services to the party. He passed out copies of a speech he'd written and later insisted that the speech was responsible for President Garfield's election. He believed the President should appoint him French consul and at one point was sending the President a daily request for this appointment. Additionally, he'd asked various Congressmen to sign a petition recommending him for the consulship. Eventually, after repeated failures to achieve his goal, he came to believe that God wanted him to kill the President.

This study was limited by the small clinical sample, a selected population (psychiatric inpatients) and inability to find meaningful controls. Full access to Secret Service files, past and present, of all such communications would immensely improve assassination research.

\section{REFERENCES}

1 D. Hastings, The psychiatry of presidential assassinations, Lancet, 3 (1965) 93"100; 4 (1965) 157-162; 5 (1965) 189-192; 7 (1965) 294-301.

2 D. Rothstein, Presidential assassination syndrome, Arch. Gen. Psychiatry, 11 (1964) $245-254$.

3 D. Rothstein, Presidential assassination syndrome Il. Application to Lee Harvey Oswald, Arch. Gen. Psychiatry, 15 (1964) 260-266.

4 A. Weisz and R. Taylor, American presidential assassinations, Dis. Nerv. Syst., 10 (1969) 659688 .

5 W. Croty, Transactions-Society, 9/7, (1972).

6 Federal Criminal Statutes, Title 18, Sect. 871, p. 41.

7 Clinical Aspects of the Violent Individual, American Psychiatric Association Task Force Report No. 8. 